\title{
TREATMENT OF PRESSURE SORES IN PARAPLEGIC PATIENTS WITH ANIMAL COLLAGEN
}

\author{
By Dr. J. W. F. M. Stoop \\ Rehabilitation Centre 'De Maasgrouv', Maastricht, Holland
}

\section{INTRODUCTION}

PRESSURE sores should be considered as a pressure phenomenon. A pressure of 50 to $60 \mathrm{~mm}$. mercury on the skin causes ischaemia. If this pressure is continued for 12 hours, death of the tissues can be the result. With paraplegics there are a number of predisposing factors causing on earlier death of the tissues.

Some of the factors are that with paraplegics we are not dealing with a healthy skin but with a disturbed neurological area. The restricted mobility of the patient can cause a prolonged pressure on the sitting or lying areas. The circulation of the paralysed extremities is lessened. Faeces and urine of the incontinent patient can reduce the resistance of the surrounding tissues. Due to disturbances of sensibility damage to the tissue may not be felt or only slightly and can therefore have a prolonged effect. Aids used to improve the mobility of the patient, e.g. splints, can be the cause of protracted pressure areas.

Predisposing areas for pressure sores are those places where the skin is stretched over the bone. These are mainly the trochanters, malleoli and the sacrum. The presence of pressure sores seriously retards the rehabilitation process. It can often be very difficult to mobilise the patient especially when the pressure sore is localised sacrally near the coccyx. The presence of pressure sores causes the general condition of the patient to worsen. Often there is a rise in temperature due to infection of the wound. With incontinent patients this infection is easily increased by contamination with bacteria from the urine and faeces. The patient loses many electrolytes and protein from the wound and this combined with a bad appetite causes a hypoprotinemia. This hinders the construction of new tissue necessary to close the wound.

Anaemia is often present. The wounds are often deeply corroded, undermined and sinuses appear which are filled with pus. A sepsis can arise. A deeper penetration of the wound can cause osteomyelitis of the underlying bone and the surrounding muscle can show a picture of myositis ossificans.

Surgical treatment of pressure sores is often made difficult because the wounds are large, the general condition of the patient has worsened and the tissue surrounding a pressure sore is often unhealthy. Moreover, autotransplantation produces another wound as the patient himself is the donor.

The conservative treatment by reducing pressure on the wounds, supplying protein, fighting infection, local applications, etc., has success only after a long period of time, as the wounds have little tendency to form granulation tissue. In the rehabilitation centre 'De Maasgouw' in Maastricht, we have been searching for an additional method of treatment, in order to stimulate quicker granulation of the pressure sore and stop the loss of protein.

\section{MATERIAL}

We have treated the sores with a collagen foil of animal source originating from calves and young pigs, which has been developed by Wanke, Grözinger, 
Hartmann and Sebening (1965, 1966, 1967) in collaboration with the firm of Braun in Melsingen, whereby use was made of the experiments done by Thiele (I967). Collagen is 72 per cent. of the weight of dry skin. It forms a threedimensional plaitwork of fibres which get closer as they get deeper and in which elastic fibres are plaited. Loiseleur (1930), Battista (1949), Watson and Rothbard (I949) have pointed out that collagen is a very weak antigen. The activity and results of this collagen foil covering the wounds of rats, rabbits and pigs, has been described by the above-mentioned scientists. From this we take some data. The collagen foil, which has the consistency of foam, has a semipermeable membrane on top which admits $\mathrm{O}_{2}$ and prevents drying out. This porous collagen is applied to the floor of the wound. It forms the skeleton in which the newly formed granulation tissue can grow out as buds or fingers. The pores of this collagen are neither so large that drying out can take place nor so small that the new granulation tissue meets resistance and bad conditions for penetration are created.

The fluid which is full of cells is absorbed by the foam-plastic-like substance. By the disintegration of leucocytes protease is liberated which is supposed to be responsible for the slow lysis of the collagen.

The collagen is broken down to particles that do not act as antigens. The resulting amino acids and peptides may possibly be used again by means of diffusion through the granulation tissue. In spite of this lysis the contact between the foil and floor of the wound remains.

Therefore, between the floor of the wound and the foil there remains a constant state; $\mathrm{pH}$, ions, composition of proteins, cellular elements and $\mathrm{O}_{2}$. Through the capillary working of the foam foil the wound secretion is absorbed in the foil. This layer of secretion contains a defence mechanism, such as leucocytes, which serve as a kind of advance defence.

\section{METHOD OF TREATMENT}

I. The necrotic tissue is removed from the wound.

2. The wound is cleaned with a sterile I per cent. hibitane solution in water.

3. The wound is dried with sterile gauze.

4. The collagen implant is wetted under sterile conditions with $\mathrm{NaCl}$ solution 0.9 per cent. in water.

5. The collagen is put on the floor of the wound.

6. This is covered with optulle to prevent movement of the implant. The optulle is fixed with 'leukopor'.

7. A few layers of bandage gauze are put on top of this.

8. This is covered with thick bandages, which are again fixed with 'leukopor'.

9. Serum protein levels in blood, haemoglobin, temperature and sedimentation rate in blood are noted as necessary.

IO. At the beginning of the treatment the collagen foil is changed every two to three days, as the collagen soon disintegrates. After two weeks this time could be lengthened. The quick changing of the collagen foil was especially necessary with pressure sores where it was not always possible to prevent pressure on the wound.

Sometimes we had to divert from the direction for use, prescribed for this implant, as the circumstances with paraplegics sometimes required it.

I. The pressure sores of paraplegics can be very undermined. We strived 
to stop the undermining. For this the membrane of the collagen foil was removed and the remaining collagen was pushed into the undermined edge.

2. One pressure sore had a size of almost $90 \mathrm{~cm} .{ }^{2}$. The implant which we had at our disposal was however $5 \mathrm{~cm} .{ }^{2}$. It was therefore necessary to work with a mosaic of collagen which had the shape of the wound.

3. As the full immobilisation of the patient was sometimes not advisable, the implant got easily displaced while the patient was mobile. After removal of the semipermeable membrane, the implant remained in place.

4. Because of the necessary mobilisation of the patient and the presence of pressure sores on various parts of the body of the patient, undesired pressure on the implant could not always be prevented.

As the collagen foil has been at our disposal for a few months we have been able to treat five patients with this collagen foil. They were all paraplegics.

The pressure sores differed according to type, size and localisation.

In total we treated I I pressure sores.

\section{CASE REPORTS}

Patient S., a 45-year-old man with a complete lesion at the level of T8. Admission date to our centre, 23 April 1969. General condition moderate, serious contractures present.

\section{Localisation:}

At the level of T8: two pressure sores of each $4 \mathrm{~cm}^{2}$ and $5 \mathrm{~mm}$. deep.

Sacrum:

Left calf: area of pressure sore $25 \mathrm{~cm} .^{2}$ and $3 \mathrm{~mm}$. deep.

Right calf: area of pressure sore $\mathrm{I} \cdot 5 \mathrm{~cm} .{ }^{2}$ and $3 \mathrm{~mm}$. deep.

Results after four weeks' treatment with collagen foil:

Sacrum: closed wound and complete epithelialisation.

Left calf: closed wound and complete epithelialisation.

Right calf: wound filled with granulation tissue.

T8 area: $\quad$ wound filled with granulation tissue.

Results after eight weeks' treatment with collagen foil:

Right calf: wound closed and complete epithelialisation.

T8 area: wound closed and complete epithelialisation.

Patient V., a 34-year-old man with an almost complete lesion at level T9, Tro. Readmission date to our centre, 5 March 1969. General condition bad. On I7 March sedimentation rate was $102 \mathrm{~mm}$. in the first hour, haemoglobin 65 per cent., temperature $39 \cdot 3^{\circ} \mathrm{C}$.

\section{Localisation:}

Right trochanter: area of pressure sore $36 \mathrm{~cm}^{2}$ and $\mathrm{I} \frac{1}{2} \mathrm{~cm}$. deep. Trochanter major completely visible and corroded. Much necrotic tissue in the wound and in the surounding tissue. Deeply undermined edges.

Left trochanter: area of pressure sore $90 \mathrm{~cm} .{ }^{2}$ and $\mathrm{I} \frac{1}{2} \mathrm{~cm}$. deep. Much necrotic tissue.

Sacrum: Wound contains much pus and fluid. Deeply undermined edges. 
Results after eight weeks' treatment with collagen foil:

Sedimentation rate was $52 \mathrm{~mm}$. in the first hour, haemoglobin 76 per cent., temperature $36 \cdot 7^{\circ} \mathrm{C}$.

Right trochanter: undermined edges of the wound are completely closed, area $20 \mathrm{~cm} .{ }^{2}$. The wound is almost completely filled with healthy granulation tissue. The wound is clean.

Left trochanter: undermined edges of the wound are closed. Area $30 \mathrm{~cm} .{ }^{2}$. The wound is filled to the edges with healthy granulation tissue. The wound is clean.

Sacrum: $\quad$ wound well closed and complete epithelialisation.

Patient P., a 39-year-old man with a complete lesion at the level of $\mathrm{T}_{7}$. Admission date to our centre, 2I October I968. The sacrum area showed a moist pressure sore fissure of length $3 \mathrm{~cm}$., I $\mathrm{cm}$. wide and $\frac{1}{2} \mathrm{~cm}$. deep. The wound did not react to any treatment.

Results after two weeks' treatment with collagen foil:

Complete closure of the fissure, however, with hypergranulation and hyperkeratosis.

Patient F., a 43-year-old woman with an incomplete lesion at the level of $\mathrm{L}_{3}$. Readmission date to our centre, 3I January I969.

The sacrum showed a fissure $2 \mathrm{~cm}$. long, $\frac{1}{2} \mathrm{~cm}$. wide and $\frac{1}{2} \mathrm{~cm}$. deep. This fissure had been present for 20 months and showed no tendency to heal.

Result after I I days' treatment with collagen foil:

Complete closure of the wound and complete epithelialisation.

Patient G., a I5-year-old boy with a total lesion at the level of Tro. Admission date to our centre, 30 September I968. Patient had a pressure sore at the level of Tio on the back. This wound was superficial, only the epithelium had disappeared. This was probably caused by rubbing in bed. He was a restless patient. The wound had been present for three months and did not react to any treatment.

Result after I4 days' treatment with collagen foil:

Completely closed and well epithelialised wound.

\section{RESULTS AND DISCUSSION}

In the treatment of pressure sores in paraplegic patients with animal collagen, we have arrived at a number of findings. The experiment is by no means finished and not all end-results are available.

I. After the application of the collagen foil the wounds were clean and bacterial infection retarded.

2. The drainage of wound secretion was diminished.

3. The formation of new granulation tissue was improved.

4. The undermined edges of the pressure sores were closed.

5. The formation of epithelium was stimulated.

6. The closed wounds showed no contractures.

7. Moist pressure sore fissures which showed no tendency to heal were closed.

8. Immunological reactions towards the collagen were not observed.

9. The general condition of the patient was improved. 
The clinical findings confirm the results of the experiments on animals by Wanke, Grözinger, Sebening, Hartmann, Collins and Linder (I965-I969).

The findings of Hinderer (1967) in the use of collagen foil in the closing of ten human skin defects (two burns, four defects, caused by skin transplantation and four old defects) are confirmed by our findings.

The publications about the treatment of human skin with animal collagen are after all very limited.

The possibility exists to close large skin defects by means of animal collagen in a relatively short time. Not only superficial skin defects are closed, but also defects of greater depth where there is also a tendency not to heal.

\section{SUMMARY}

I. Pressure sores in paraplegic patients have little tendency to heal.

2. From April I969 to July I969, five paraplegic patients with together II pressure sores of various sizes, depths and localisations were treated in the rehabilitation centre 'De Maasgouw', Maastricht, Holland, with collagen foil of animal origin, which has been developed by Braun to close human skin defects.

3. The method of treatment has been described.

4. During the period of observation seven pressure sores were closed completely and four pressure sores were considerably levelled off and the size well diminished.

5. The clinical findings confirm the results of experiments on animals.

\section{ZUSAMMENFASSUNG}

I. Druckgeschwüre bei spinal Gelähmten haben eine geringe Heilungstendenz.

2. Vom April 1969 bis Juli 1969, wurden 5 Patienten mit zusammen I I Druckgeschwüren im Rehabilitationszentrum 'De Maasgrouw' mit 'collagen foil' vom Tier behandelt, das von Braun für die Therapie von Hautdefekten entwickelt wurde.

3. Die Methode wird beschrieben.

4. Während der Beobachtungsperiode heilten 7 Druckgeschwüre völlig, bei 4 waren Umfang und Tiefe vermindert.

5. Die klinischen Befunde bestätigen die Tiererperimente.

\section{RÉSUMÉ}

Les escarres chez les paraplégiques ont peu de tendances à guérir.

5 paraplégiques avec au total i I escarres de différentes tailles, profondeurs et localisations ont été traitées d'avril 69 à juillet 69 avec des feuilles de collagène d'origine animale étudiées par BRAUN pour la cicatrisation des tissus humains. La méthode de traitement est décrite. Pendant la période d'observation, 7 escarres ont été complètement guéries et 4 escarres se sont considérablement comblées et leur taille réduite. Les observations cliniques confirment le résultat de l'expérimentation animale.

\section{REFERENCES}

BAKer, A. B. (1962). Clinical Neurology, Vol. 3.

Battista, A. F. (I949). Canad. F. Res. E.27, 94.

HINDERER, U. (1967). Diskussionsbeitrag zu dem Referat von Wanke, Grözinger und Sebening. Melsungen med. Mittlg. 4I, (108), 107.

Loiseleur, J. (1930). C. R. Soc. Biol. (Paris), ro3, 776.

ThIELE, H. (1967). Histolyse und Histogenese. XI Haut. Frankfurt: Akademische Verlagsges. S.I I 4 . 
Wanke, M., Grözinger, K.-H. \& Hartmann, R. (1966). Langenbecks Arch. klin. Chir. 314, 99.

Watson, R. F. \& RothbaRd, S. (1954). F. exp. Med. 99, 535.

WANKe, M., OTt, G. (1969). Erfahrungen zum temporären Hautersatz mit DreischichtKollagenfolien- (in print).

Wanke, M., Grözinger, K.-H., Hartmann, R. (1966). Langenbecks Arch. klin. Chir. 3II, I, pp. 99-I I6 (in English).

WANKE, M. (I966). Mschr. Unfallheilk. 69, 50I.

Wanke, M., Collins, R. L. L., Hartmann, R., Linder, M. M. \& Sebening, H. (I967). Frankf. Z. Path. 77, 125 .

WANKe, M. \& GRÖZINGER, K.-H. (1965). Klin. Wschr. 43. 975.

WANKE, M. \& GRöZINGER, K.-H. (I967). Wehrmed. Mschr. III, I54.

\title{
BED SORES TREATED WITH NEGATIVE AIR-IONS
}

\author{
By Dr. G. URSU \\ Institute of Physiotherapy and Motor Re-Education, Selvapiana del Circeo, Italy
}

I USED negative ionised air in the treatment of four paraplegic patients with pressure sores. I have applied this treatment in Italy under the guidance of Dr. G. Pedacchie, Director of the Institute of Physiotherapy and Motor Re-Education, Selvapiana del Circeo.

\section{INTRODUCTION}

The ionisation of air (positive or negative) can occur naturally as in cosmic radiations, ionising radiations and so on and artificially using the apparatus called the air-ions generator.

In terrestrial conditions the oxygen is that gas which can be ionised. The physical phenomenon is produced in the following way: the oxygen atom is composed of eight protons-the positive charges of atom which constitute the atomic nucleus - and eight electrons situated on the two orbits, which represent the negative charge of the atom. The electrical neutrality of the oxygen atom results from the balance of forces between electrons and protons, in other words between the negative and positive charges.

\section{METHOD}

The apparatus that we have constructed and which we are using for oxygen ionisation (from ordinary air) is producing an electronic bombardment and a disturbance of atomic balance, which results in negative and positive oxygen-ions in equal parts. By means of an electrical system the apparatus is producing the 